\title{
Prevalence and pattern of hand eczema in a tertiary referral hospital of Nepal
}

\author{
Rushma Shrestha, MD; Anupama Karki, MD \\ Department of Dermatology, National Academy of Medical Sciences, Bir Hospital, Kathmandu, Nepal
}

\section{Corresponding author}

Rushma Shrestha, MD

Email: rushma_100@yahoo.com

Received: 3 Sep 2019

Accepted: 16 Nov 2019

\begin{abstract}
\section{Background}

Hand eczema is a very common condition that has a significant effect on an individual's life in terms of daily functioning including various occupations. Studies show that the point prevalence of hand eczema is around $4 \%$ and the lifetime prevalence is $15 \%$.
\end{abstract}

\section{Objective}

The objective of this study is to determine the prevalence and pattern of hand eczemas in patients attending the Dermatology outpatient department of Bir hospital.

\section{Materials and methods}

This is a retrospective study, where all the cases of hand eczema who presented to the Dermatology Out-Patient Department of Bir Hospital during the period from Baisakh 2075 till Chaitra 2075 B.S were recorded.

\section{Results}

Eczema was diagnosed in 5,100 new cases (15.74\%) and among them, hand eczema was seen in 494 cases, which accounts for $9.68 \%$ of all eczemas. The mean age was 37.43 years. Out of all the hand eczemas recorded, 334 (67.6\%) were unspecified hand eczemas, pompholyx was seen in 92 (18.6\%) cases, chronic hand eczema in 27 (5.5\%), contact dermatitis in 20 (4\%) patients and finger tip eczema was seen in 15 (3\%) cases.

\section{Conclusion}

Hand eczema is one of the common dermatological conditions. Our study showed the prevalence of hand eczema to be $9.68 \%$.

Key words: Hand eczema, Itch, Spongiosis.

\section{Introduction}

Eczema is an inflammatory condition of skin, characterized by pruritus and range of signs like vesiculation, erythema, scaling and lichenification, and histologically characterized by spongiosis ${ }^{1}$. There are various classifications of eczema, like, endogenous and exogenous eczema, according to the severity: acute, sub-acute and chronic. They are also classified according to site: hand eczema, ear eczema, eyelid dermatitis, nipple eczema, and so on ${ }^{2}$.

Hand eczema is a very common skin condition that has a significant effect on an individual's life in terms of daily functioning ${ }^{3}$ including various occupations ${ }^{4}$. Studies show that the point prevalence of hand eczema is around $4 \%$ and the 
lifetime prevalence is $15 \%{ }^{5}$. It can occur due to endogenous factors (e.g. pompholyx) as well as exogenous factors (e.g. irritant contact dermatitis, allergic contact dermatitis). It is one of the most common occupational dermatitis comprising up to $80 \%$ or more of all occupational contact dermatitis ${ }^{6}$.

Very few studies are reported from Nepal on hand eczema, thus, the aim of this study is to find the prevalence of hand eczema at our center as it is one of the largest referral centers of the country.

\section{Materials and Methods}

This is a retrospective study, where all the cases of hand eczema who presented to the Dermatology Out-Patient Department (OPD) of Bir Hospital during the period from 15th April 2018 till 12th April 2019 (Baisakh 2075 till Chaitra 2075 B.S) were recorded from the OPD register.

\section{Results}

Total number of patients who presented to the Dermatology OPD of Bir Hospital during the study period was 49,277. Eczema was diagnosed in 5,100 new cases (15.74\%) and among them; hand eczema was seen in 494 cases, which accounts for $9.68 \%$ of all eczemas. Frequency of Eczema in males was slightly higher than in females (male:female- 260:234). The age of the patients presenting with hand eczema ranged from 3 years to 90 years (Table 1 ). The mean age was 37.43 years (standard deviation, 16.48). The mean age of females was 37 years and that of males was 38 years. Maximum numbers of cases were seen in working age group adults between $20-39$ years of age.

Table 1. Distribution of age

\begin{tabular}{|c|c|c|}
\hline Age in years & No. of patients & Percentage \\
\hline $0-9$ & 13 & 2.63 \\
\hline $10-19$ & 43 & 8.70 \\
\hline $20-29$ & 115 & 23.28 \\
\hline $30-39$ & 126 & 25.51 \\
\hline $40-49$ & 80 & 16.19 \\
\hline $50-59$ & 51 & 10.32 \\
\hline $60-69$ & 38 & 7.69 \\
\hline $70-79$ & 25 & 5.06 \\
\hline$\geq 80$ & 3 & 0.61 \\
\hline Total & 494 & 100.00 \\
\hline
\end{tabular}

Out of all the hand eczemas recorded, 334 (67.6\%) belonged to unspecified hand eczema category. Pompholyx was seen in 92 (18.6\%) cases, chronic hand eczema in 27 (5.5\%), contact dermatitis was found in 20 (4\%) patients and fingertip eczema was seen in 15 (3\%) cases (Table 2).

Four patients were diagnosed as allergic contact dermatitis ( $A C D$ ) to cement and one patient had ACD to nickel. Other causes of contact dermatitis were not specified. There was not much difference in the gender distribution of various types of eczemas.

Table 2. Pattern of hand eczema

\begin{tabular}{|c|c|c|c|c|}
\hline \multirow{2}{*}{$\begin{array}{l}\text { Type of hand } \\
\text { eczema }\end{array}$} & \multicolumn{2}{|c|}{ Gender } & \multirow{2}{*}{$\begin{array}{c}\text { No. of } \\
\text { patients }\end{array}$} & \multirow{2}{*}{$\begin{array}{l}\text { Per- } \\
\text { cent }\end{array}$} \\
\hline & $\begin{array}{c}\text { Female } \\
\mathbf{N}\end{array}$ & Male $\mathbf{N}$ & & \\
\hline $\begin{array}{l}\text { Unspecified } \\
\text { hand eczema }\end{array}$ & 169 & 165 & 334 & 67.6 \\
\hline Pompholyx & 35 & 57 & 92 & 18.6 \\
\hline $\begin{array}{l}\text { Chronic hand } \\
\text { eczema }\end{array}$ & 12 & 15 & 27 & 5.5 \\
\hline $\begin{array}{l}\text { Allergic contact } \\
\text { dermatitis }\end{array}$ & 9 & 10 & 19 & 3.8 \\
\hline $\begin{array}{l}\text { Irritant contact } \\
\text { dermatitis }\end{array}$ & 0 & 1 & 1 & 0.2 \\
\hline $\begin{array}{l}\text { Fingertip } \\
\text { eczema }\end{array}$ & 7 & 8 & 15 & 3 \\
\hline Palmar peeling & 1 & 2 & 3 & 0.6 \\
\hline $\begin{array}{l}\text { Infected hand } \\
\text { eczema }\end{array}$ & 1 & 1 & 2 & 0.4 \\
\hline $\begin{array}{l}\text { Subacute hand } \\
\text { eczema }\end{array}$ & 0 & 1 & 1 & 0.2 \\
\hline Total & 234 & 260 & 494 & 100 \\
\hline
\end{tabular}

Most of the patients with hand eczema presented in the months of August-September, and the frequency of patients was less in NovemberJanuary (Table 3).

\section{Discussion}

Hand eczema is a frequently encountered condition of skin that is confined to the hands ${ }^{7}$. In this study, we found that the prevalence of hand eczema was $9.68 \%$ of all eczemas which is similar to the study done by Thyssen et al., where 1 year prevalence of hand eczema was around $10 \% 5$.

Various studies have shown that the incidence was more in females than males ${ }^{8,9}$, while others have reported that the incidence is increasing in men $^{10}$. 
However, our study did not show much difference between males and females.

Table 3. Frequency of patients according to month

\begin{tabular}{|l|c|c|c|c|}
\hline \multicolumn{1}{|c|}{$\begin{array}{c}\text { Month of } \\
\text { 2075 B.S. }\end{array}$} & \multicolumn{2}{|c|}{ Gender } & $\begin{array}{c}\text { No. of } \\
\text { patients }\end{array}$ & $\begin{array}{c}\text { Per- } \\
\text { cent }\end{array}$ \\
\cline { 2 - 5 } Baisakh & 24 & 29 & 53 & 10.7 \\
\hline Jestha & 26 & 28 & 54 & 10.9 \\
\hline Asadh & 18 & 24 & 42 & 8.5 \\
\hline Shrawan & 15 & 29 & 44 & 8.9 \\
\hline Bhadra & 28 & 28 & 56 & 11.3 \\
\hline Asoj & 26 & 24 & 50 & 10.1 \\
\hline Kartik & 26 & 23 & 49 & 9.9 \\
\hline Mangsir & 18 & 9 & 27 & 5.5 \\
\hline Poush & 20 & 14 & 34 & 6.9 \\
\hline Magh & 9 & 18 & 27 & 5.5 \\
\hline Falgun & 10 & 18 & 28 & 5.7 \\
\hline Chaitra & 14 & 16 & 30 & 6.1 \\
\hline Total & $\mathbf{2 3 4}$ & $\mathbf{2 6 0}$ & $\mathbf{4 9 4}$ & $\mathbf{1 0 0}$ \\
\hline
\end{tabular}

Most of our patients belonged to the age group of 3039 years, which is similar to the findings by Ibrahim et al. ${ }^{11}$. In this study the mean age was 37.42 years. The mean age of females and males was 37 years and 38 years respectively, which is slightly higher than the study conducted by Chitte et al. where the mean age was 34.07 years, female mean age 31.78 years and male mean age 36.09 years ${ }^{12}$.

Our study showed that most of the patients presented with unspecified type of hand eczema (67.6\%) followed by pompholyx (18.6\%), which is similar to the study by Handa S et al., where they found unspecified hand eczema to be $62 \%$ and pompholyx $14 \%{ }^{10}$.

We found that most of the patients presented with hand eczema during the months of Baisakh, Jestha and Bhadra, Asoj. This could be because, a large proportion of Nepalese population depend on agriculture, and summer and spring seasons are most favorable for farming and they get exposed to various kinds of external agents ${ }^{13}$.

Our study had certain limitations. This was a retrospective study. Details like occupation and causative agents of hand eczema were not included. We have planned a prospective study in a larger population to determine various causes of hand eczema.

\section{Conclusion}

Hand eczema is one of the common dermatological conditions which tend to run a long lasting and chronic relapsing course probably because of the multifactorial origin. Our study showed the prevalence of hand eczema, among all the eczemas, to be $9.68 \%$. As this condition is often associated with itch, social stigma and impairment in employment, more emphasis should be given on prevention of relapses of hand eczemas and thus reducing the burden of disease.

\section{References}

1. Ingram JR. Eczematous disorders. In: Rook's textbook of dermatology. Griffiths CEM, Barker J, Bleiker T, Chalmers R, Creamer D editors. $9^{\text {th }}$ ed. UK, West Sussex: Wiley Blackwell;2016;Vol 2 p.39.1-39.7.

2. James WD, Berger TG, Elston DM. Atopic dermatitis, eczema and noninfectious immunodeficiency disorders. In: Andrews' diseases of the skin clinical dermatology. $11^{\text {th }}$ ed. USA: Saunders Elsevier;2011;69-75.

3. Hald M, Agner T, Blands J, Johansen JD. Quality of life in a population of patients with hand eczema: A six month follow-up study. Acta Derm Venereol 2011;91:484-486.

4. Agarwal US, Besarwal RK, Gupta R, Agarwal P, Napalia S. Hand eczema.Indian J Dermatol 2014;59(3):213-224.

5. Thyssen JP, Johansen JD, Linneberg A, Menne T. The epidemiology of hand eczema in the general population-prevalence and main findings. Contact Dermatitis. 2010;62:75-87.

6. Agarwal US, Besarwal RK, Gupta R, Agarwal P, Napalia S. Hand eczema.Indian J Dermatol. 2014;59(3):213-224.

7. Coenraads PJ. Hand eczema is common and multifactorial. J Invest Dermatol 2007;127:1568-1570.

8. Meding B, Jarvholm B. Incidence of hand eczema-a population-based retrospective study. J Invest Dermatol 2004;122(4):873-877.

9. Johannisson A, Ponten A, Svensson A. Prevalence, incidence and predictive factors for hand eczema in young adults-a follow-up study. BMC Dermatol 2013;13:14. 
10. Handa S, Kaur I, Gupta T, Jindal R. Hand eczema: Correlation of morphologic patterns, atopy, contact sensitization and disease severity. Indian J Dermatol Venereol Leprol 2012;78:153-8.

11. Ibrahim $Y$, Chandran $R$, George AE. Patch test positivity in hand eczema. Journal of Medical Science and Clinical Research 2018;6(10):736-741.
12. Chitte R, Gugle A, Deshmukh M. Clinical profile and patch test results among hand eczema patients at a tertiary care institute. MVP Journal of Medical Sciences 2017;4(2): 118-125.

13. Poudel S, Kotani K. Climatic impacts on crop yield and its variability in Nepal: Do they vary across seasons and altitudes? Climatic Change 2013;116(2):327-355. 